\title{
Caracterização e diversidade genética de cultivares de morangueiro
}

Elizete Beatriz Radmann $^{1,3}$; Valmor João Bianchi ${ }^{1}$; Roberto P. de Oliveira ${ }^{2,4}$; José Carlos Fachinello ${ }^{1}$

${ }^{1}$ Universidade Federal de Pelotas, FAEM, Dep ${ }^{\text {to }}$ Fitotecnia, C. Postal 354, 96010-900 Pelotas-RS; E-mail: eradmann@gmail.com; ${ }^{2}$ Embrapa Clima Temperado, C. Postal 403, 96001-970 Pelotas-RS; E-mail: rpedroso@cpact.embrapa.br; ${ }^{3}$ Aluna doutorado UFPel; ${ }^{4}$ Bolsista $\mathrm{CNPq}$

\section{RESUMO}

O objetivo deste trabalho foi caracterizar a diversidade genético-molecular, por marcadores RAPD, das dez principais cultivares de morangueiro utilizadas no País: Aromas, Bürkley, Camarosa, Campinas, Dover, Milsei-Tudla, Oso Grande, Santa Clara, Sweet Charlie e Vila Nova. O DNA foi extraído de folhas maduras, as análises RAPD foram realizadas com 26 primers e os produtos de amplificação separados por eletroforese. O coeficiente de Dice foi utilizado para estimar a similaridade genética entre as cultivares e o método UPGMA para gerar o fenograma por meio do NTSYS. Houve amplificação de fragmentos consistentes com 19 primers, tendo sido encontrado polimorfismo em 14. Dos 116 fragmentos gerados, 84 foram polimórficos. As cultivares foram classificadas em dois grupos principais quanto à similaridade genética: cultivares destinadas à industrialização (Bürkley, Santa Clara e Vila Nova) e cultivares destinadas ao mercado in natura (demais cultivares). A similaridade foi menor no grupo das cultivares para consumo in natura (44-74\%), o que ocorreu em função dos parentais serem diferentes. A maior similaridade genética ocorreu entre as cultivares de indústria Santa Clara e Vila Nova (98\%), ambas obtidas pelo programa de melhoramento da Embrapa Clima Temperado, e provenientes dos mesmos parentais ('Konvoy-Cascata' e 'Lassen'). Padrões RAPD foram estabelecidos para a caracterização genética das dez cultivares de morangueiro estudadas.

Palavras-chave: Fragaria x ananassa Duch., RAPD, fingerprint, marcador molecular.

\begin{abstract}
Characterization and genetic diversity of strawberry cultivars
\end{abstract}

In this work we characterized the genetic-molecular diversity by RAPD markers of the main ten strawberry cultivars cultivated in Brazil: Aromas, Bürkley, Camarosa, Campinas, Dover, Milsei-Tudla, Oso Grande, Santa Clara, Sweet Charlie and Vila Nova. The DNA was extracted from mature leaves, the RAPD analysis were carried out with 26 primers and the amplification products were separated by electrophoreses. The coefficient of Dice was used to estimate the genetic similarity among the cultivars and the UPGMA method to obtain the phenogram using NTSYS software. Bands were amplified with 19 primers, and showed polymorphism with 14 . Out of 116 bands, 84 were polymorphic. The cultivars were classified in two main groups: industry cultivars (Bürkley, Santa Clara and Vila Nova) and fresh fruit market cultivars (other cultivars). The genetic similarity was lesser in the group of cultivars for fresh market (44$74 \%$ ), in which the different clones were used as parents. The cultivars Santa Clara and Vila Nova, used for processing, showed the higher genetic similarity (98\%), both cultivars were obtained at breeding program of Embrapa Clima Temperado, and are originated from the same parental clones ('Konvoy-Cascata' and 'Lassen'). Standard RAPD markers were established to genetic characterization of ten strawberry cultivars.

Keywords: Fragaria x ananassa Duch., RAPD, fingerprint, molecular marker.

(Recebido para publicação em 31 de março de 2005; aceito em 14 de setembro de 2005)

$\mathrm{O}$ morangueiro (Fragaria $\mathrm{x}$ ananassa Duch.) pertence à família das Rosaceas, sendo um híbrido resultante das espécies americanas $F$. Chiloensis, F. Virginiana e F. Ovalis, e da européia Fragaria vesca (Ronque, 1998).

No Brasil, a cultura encontra-se difundida em regiões de clima temperado e sub-tropical, onde se produz morango para consumo in natura e também para industrialização. Trata-se de uma importante atividade econômica, principalmente em pequenas propriedades rurais que utilizam mão-de-obra familiar.

A produção brasileira está estimada em 90 mil toneladas por ano, sendo obtida em uma área aproximada de 3.600 ha, destacando-se os estados de Minas Gerais (32,3\%), São Paulo (31,4\%) e Rio Grande do Sul (16,5\%) como maiores produtores (Reichert \& Madail, 2003).

No País, na década de 70, houve um incremento significativo da produção de morango quando a Embrapa Clima Temperado, o Instituto Agronômico de Campinas (IAC) e outras instituições passaram a utilizar a cultura de meristema para limpeza de viroses e propagação in vitro em larga escala. Com o passar dos anos, outras ferramentas biotecnológicas foram desenvolvidas e têm sido utilizadas no estudo do gênero Fragaria, principalmente relacionadas à caracterização e à diversidade genéti- ca (Assis, 2004). A fidelidade genética das cultivares é de fundamental importância na cultura do morangueiro, pois a renovação da cultura é, geralmente, anual e existem dezenas de cultivares bastante semelhantes morfologicamente.

Até há pouco tempo, a caracterização morfo-fenológica constituía a base para os trabalhos de diferenciação e de estimativas de similaridade genética entre cultivares de morangueiro (Conti et al., 2002). Mais recentemente, análises bioquímicas, por meio de isoenzimas, e moleculares passaram a ser utilizadas com essa finalidade. As análises por isoenzimas têm gerado um pequeno número de marcadores genéti- 
cos, impossibilitando, na maioria das vezes, a caracterização adequada (Thongthieng \& Smitamana, 2003). A técnica de RAPD (DNA polimórfico amplificado ao acaso), desenvolvida por Williams et al. (1990), é considerada uma metodologia de fácil e rápida aplicação em relação às outras técnicas moleculares, como RFLP, SSR e AFLP, permitindo a obtenção de polimorfismo genético a partir de pequena quantidade de DNA e produzindo mais polimorfismo em relação aos marcadores morfo-fenológicos e isoenzimáticos (Ferreira \& Grattapaglia, 1996). Por esses motivos, atualmente, os marcadores RAPD estão entre os mais utilizados em estudos genéticos de diversas espécies frutíferas, tais como ameixeira (Bianchi et al., 2003), citros (Oliveira et al., 2001), pessegueiro (Lima et al., 2003) e morangueiro (Thongthieng \& Smitamana, 2003).

O presente trabalho teve por objetivo caracterizar a diversidade genética das dez cultivares de morangueiro mais utilizadas no Brasil, por meio de marcadores RAPD.

\section{MATERIAL E MÉTODOS}

O trabalho foi conduzido no Laboratório de Caracterização Molecular de Plantas Lenhosas, da Faculdade de Agronomia Eliseu Maciel (FAEMUFPel). Folhas jovens, completamente desenvolvidas, foram coletadas de cinco plantas de dez cultivares de morangueiro mantidas em casa de vegetação no matrizeiro da Embrapa Clima Temperado. As cultivares avaliadas foram: Aromas, Bürkley, Camarosa, Campinas, Dover, Oso Grande, Santa Clara, Sweet Charlie, Milsei-Tudla e Vila Nova.

O DNA genômico das cultivares foi extraído a partir de seis discos foliares, coletados em tubo tipo eppendorf de 2 $\mathrm{ml}$, sendo as amostras armazenadas a $80^{\circ} \mathrm{C}$. A extração de DNA foi realizada segundo protocolo descrito por Mulcahy et al. (1993), com algumas modificações propostas por Bianchi et al. (2003).

O DNA foi quantificado em minigel de agarose $0,8 \%$. A estimativa da concentração de DNA foi realizada com base na comparação da intensidade das bandas com padrão de DNA 1Hind III.

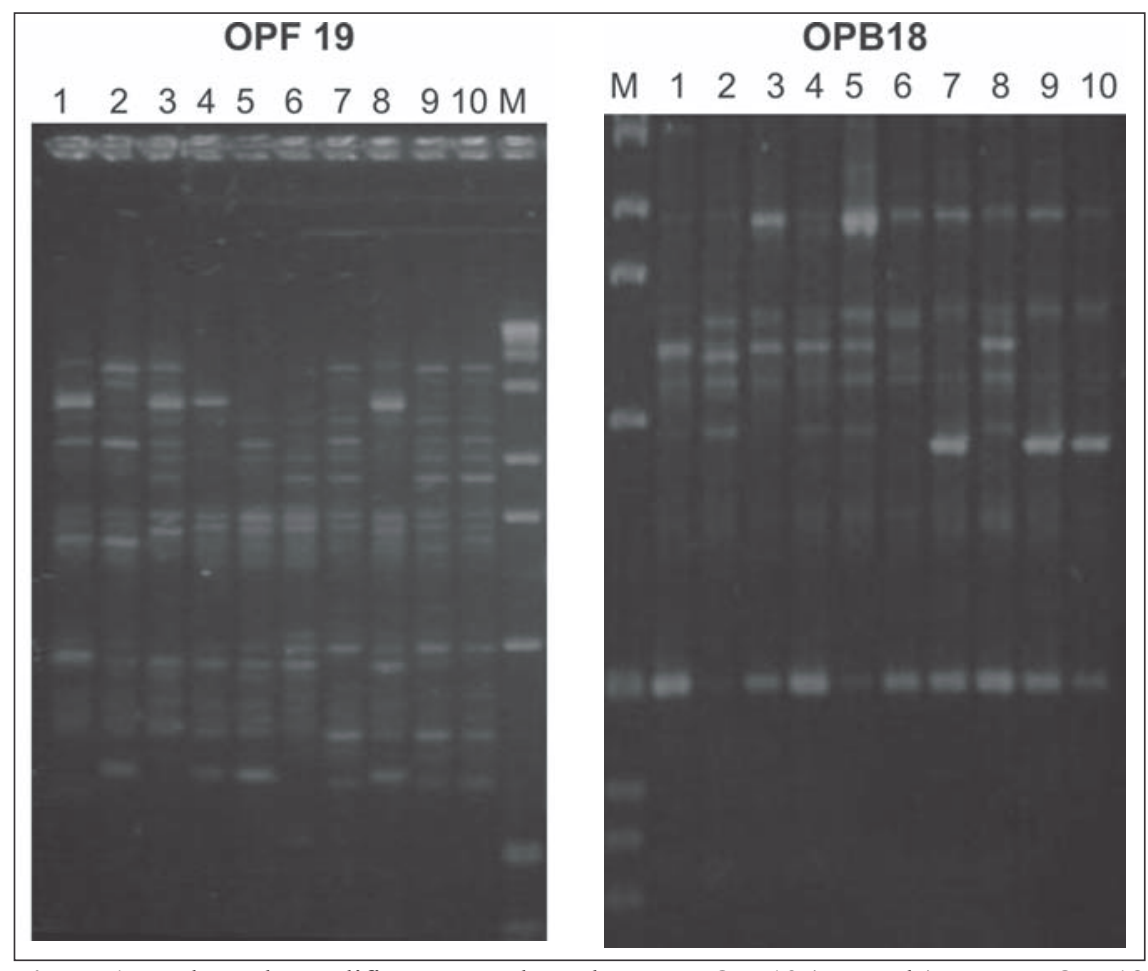

Figura 1. Produtos de amplificação gerados pelo primer OPF19 (esquerda) e primer OPB18 (direita) nas cultivares Dover (1), Campinas (2), Milsei-Tudla (3), Camarosa (4), Aromas (5), Sweet Charlie (6), Santa Clara (7), Oso Grande (8), Vila Nova (9) e Bürkley (10). Marcador de peso molecular $1 \mathrm{~Kb}(\mathrm{M})$. Pelotas, UFPel/Embrapa Clima Temperado, 2005.

As amostras foram diluídas em água, para uma concentração final de $15 \mathrm{ng}$ $\mathrm{mL}^{-1}$, para utilização na reação de polimerase em cadeia (PCR).

Para as amplificações foram utilizados primers decâmetros dos Kits da Operon Technologies Inc. (A1, B1, B2, B3, B5, B6, B7, B9, B10, B13, B14, B16, B17, B18, B19, B20, F2, F6, F7, F11, F13, F14, F19, AC4, AC19, AF11) e da British Columbia University - UBC (UBC 407 e UBC 412). As reações de amplificação foram realizadas com um volume total de $25 \mathrm{ml}$, contendo: tampão 10x (10 mM Tris-HCl pH 9,0; $50 \mathrm{mM} \mathrm{KCl}) ; \mathrm{MgCl}_{2}(1,6$ $\mathrm{mM})$; primer $(0,3 \mathrm{mM})$; dNTPs $(200 \mathrm{mM}$ cada); Taq DNA polymerase Invitrogem (1,0 unidade); e 40 ng de DNA. As amplificações foram realizadas em aparelho termociclador MJ PTC-200, programado nas seguintes condições: pré-desnaturação de 2 min a $94^{\circ} \mathrm{C}$, seguida de 45 ciclos de 45 segundos a $94^{\circ} \mathrm{C}, 1 \mathrm{~min}$ a $37^{\circ} \mathrm{C}, 1 \mathrm{~min}$ a $72^{\circ} \mathrm{C}$, com extensão final de $5 \mathrm{~min} \mathrm{a}$ $72^{\circ} \mathrm{C}$. Os fragmentos amplificados foram separados por eletroforese horizontal, em gel de agarose a 1,5\%, a $200 \mathrm{~mA}$.

Os perfis eletroforéticos das cultivares foram comparados buscando-se identificar os marcadores polimórficos úteis para estabelecer um padrão de identificação seguro e inequívoco.

Para o estudo da diversidade genética, os produtos da amplificação foram usados para a construção de uma matriz de similaridade, a qual foi elaborada pelo registro de presença (1) ou ausência (0) de bandas RAPD para cada cultivar. A similaridade entre as cultivares foi calculada com base no coeficiente de Dice, com auxílio do aplicativo NTSYS versão 1,8 (Rohlf, 1993). Com base na análise de similaridade, foi construído o dendrograma de agrupamento das cultivares, empregando-se o método UPGMA (Uniweighted Pair Group Mean Average).

\section{RESULTADOS E DISCUSSÃO}

Com base nos resultados das amplificações dos 28 primers testados, foram selecionados 19 para análise genética das cultivares. Destes, 14 produziram fragmentos polimórficos (B1, B3, B5, B6, B7, B10, B14, B18, B20, F6, F7, $\mathrm{F} 19, \mathrm{AF} 11$ e UBC 407) e cinco primers foram monomórficos (B13, B17, F2, 


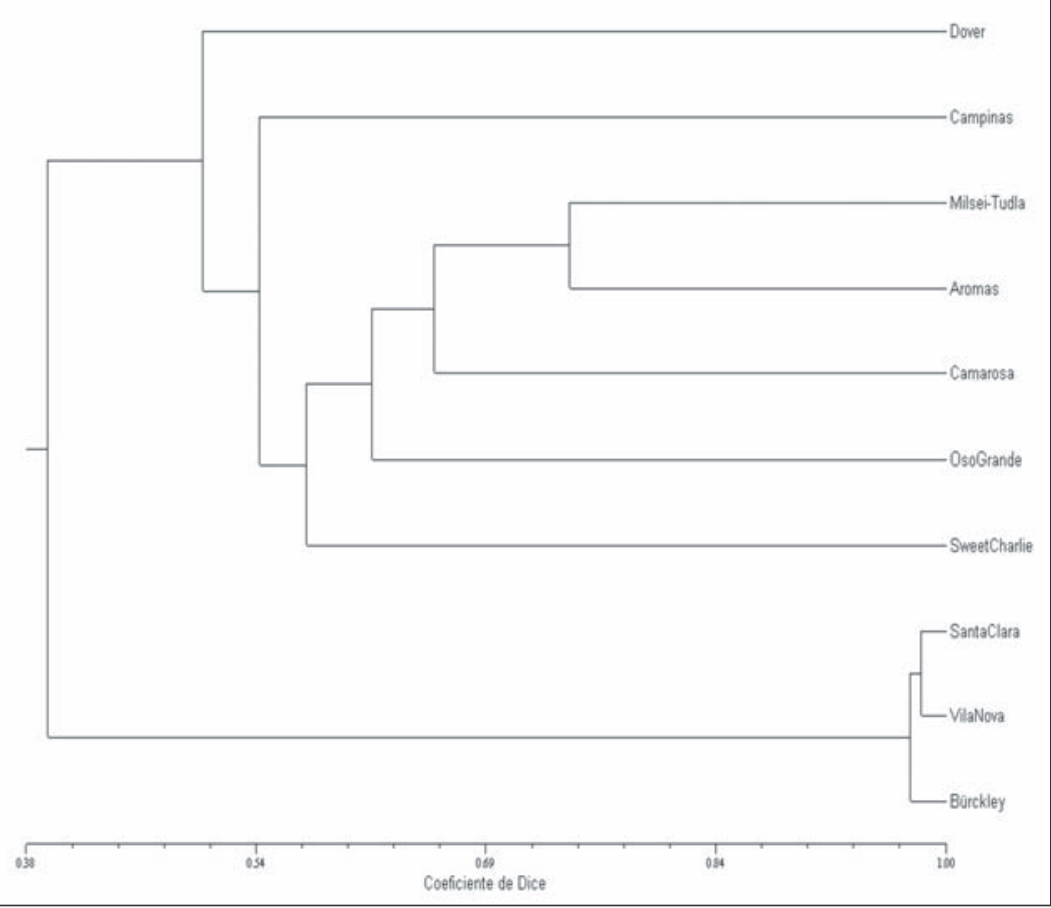

Figura 2. Dendrograma de similaridade genética entre 10 cultivares de morangueiro, obtido a partir de marcadores RAPD, utilizando o método UPGMA. Pelotas, UFPel/Embrapa Clima Temperado, 2005.

F13 e UBC 412). Com os primers que geraram bandas polimórficas, obteve-se um total de 116 fragmentos, dos quais $84(73 \%)$ foram polimórficos e 32 (27\%) monomórficos. Foram amplificadas, em média, seis bandas consistentes por primer, variando de 1 (B10) a 14 (B5). Hancock \& Callow (1994) e Thongthieng \& Smitamana (2003), usando marcadores RAPD na caracterização de morangueiro, obtiveram média de 2,8 e 12,1 bandas por primer, respectivamente.

Os marcadores B5, F19 e B7 destacaram-se com relação aos demais, produzindo 14, 11 e 13 fragmentos polimóficos, respectivamente. Nos trabalhos desenvolvidos por Degani et al. (1998) e Thongthieng \& Smitamana (2003), o primer B7 também foi selecionado para análise dos dados, confirmando seu elevado polimorfismo.

O tamanho dos fragmentos obtidos neste trabalho (entre 360 e 2300 pb) está condizente com Ferreira \& Grattapaglia (1996), os quais citam que em reações de RAPD, normalmente, são amplificados fragmentos entre 500 e $2500 \mathrm{pb}$. Na Figura 1 são apresentados alguns produtos polimórficos.
Como resultado da análise de agrupamento a partir dos dados de similaridade, verificou-se a presença de dois grupos bastante distintos (Figura 2). O primeiro formado pela maioria das cultivares, as quais são destinadas para o consumo in natura ('Aromas', 'Camarosa', Campinas', 'Dover', 'Milsei-Tudla', 'Oso Grande' e 'Sweet Charlie') e um segundo grupo incluindo as cultivares mais indicadas para a indústria ('Bürkley', 'Santa Clara' e 'Vila Nova'). Dentro do primeiro grupo, a maioria das cultivares são de origem Norte Americana, com exceção da 'Campinas' e 'Milsei-Tudla', as quais foram desenvolvidas pelo IAC no Brasil, e em Tudela, na Espanha, respectivamente. Embora estas cultivares não tenham sido obtidas nos EUA, são resultantes do cruzamento entre cultivares procedentes da Universidade da Califórnia ('Donner' $x$ 'Tahoe') e ('Parker' $x$ 'Chandler'), respectivamente (Conti, 1998), o que pode justificar o agrupamento. Ainda neste grupo, podese observar que a similaridade genética é pequena, a qual pode estar relacionada com sua genealogia, pois a maioria das cultivares não tem um progenitor em comum: 'Aromas' (clone 87.112-6 x clone 88.270-1), 'Camarosa' ('Douglas' $x$ clone 85.218-605), 'Campinas' ('Donner' $x$ 'Tahoe'), 'Dover' ('Flórida' x clone Fla 71-189), 'Sweet Charlie' (clone FI 80-456 x 'Pajaro'), com exceção da cultivar Oso Grande ('Parker' x clone 773-603) e da Milsei-Tudla ('Parker' x 'Chandler') (Multiplanta, 2005 e Conti, 1998). Entretanto, a formação deste grupo pode estar vinculada ao compartilhamento de genes derivados de ancestrais comuns mais distantes, o que explica a similaridade genética existente. A maior similaridade foi observada entre as cultivares Aromas e Milsei-Tudla (74\%), embora estas não apresentem genealogia coincidente. 'Milsei-Tudla' e 'Oso Grande' têm em comum um dos pais (cultivar 'Parker'), apresentando similaridade de $56 \%$. O elevado polimorfismo verificado está de acordo com os resultados obtidos em outras cultivares de morangueiro por Conti et al. (2002), Degani et al. (1998), Hancock \& Callow (1994) e Graham et al. (1996).

No segundo grupo, as cultivares agrupadas foram lançadas pelo programa de melhoramento da Embrapa Clima Temperado, apresentando alta similaridade ( $>96 \%$ ). A maior similaridade genética foi encontrada entre as cultivares Santa Clara e Vila Nova (98\%), o que se justifica por apresentarem em comum um dos progenitores ('KonvoyCascata'). Embora estas cultivares sejam geneticamente muito semelhantes, apresentam diferença quanto ao vigor em campo. Com relação à 'Bürkley', embora não se tenha informação sobre a sua genealogia, talvez esta cultivar tenha em comum um dos pais ou avós das cultivares Vila Nova e Santa Clara, pois entre estas também foi observada alta similaridade genética (96\%).

A divergência entre as cultivares do primeiro grupo confere com as características distintas fenotipicamente e a proximidade entre aquelas do segundo grupo, semelhantes fenotipicamente, denotando a associação entre a caracterização morfo-fenológica e a molecular. Esta associação foi relatada por Conti et al. (2002), os quais verificaram concordância dos níveis de similaridade entre cultivares de morangueiro ao tra- 
balharem com características moleculares (RAPD) e morfológicas.

Os padrões RAPD obtidos para as dez cultivares estudadas são úteis para a caracterização genética desses materiais, de modo a garantir a fidelidade genética em programas de pesquisa e de produção de mudas e frutos.

\section{AGRADECIMENTOS}

À FAPERGS (Fundação de Amparo à Pesquisa do Estado do Rio Grande do Sul) pelo apoio financeiro ao projeto.

\section{LITERATURA CITADA}

ASSIS M. 2004. Produção de matrizes e mudas de morangueiro no Brasil. In: ANTUNES LE; RASEIRA MCB; GONÇALVES ED; TREVISAN R. (Ed.) Simpósio nacional do morango, 2, 2004. Pelotas: Embrapa Clima Temperado, p. 45-50 (Embrapa Clima Temperado. Documentos, 124).

BIANCHI VJ; FACHINELLO JC; SCHUCH MW. 2003. RAPDs na caracterização genético molecular e no estudo da variabilidade genética de cultivares de ameixeira. Revista Brasileira de Fruticultura, 25: 272-274.
CONTI JH; MINAMI K; TAVARES FCA. 2002. Comparação de caracteres morfológicos e agronômicos com moleculares em morangueiros cultivados no Brasil. Horticultura Brasileira, 20: 419-423. CONTI JH. 1998. Estudo de caracteres morfológicos, agronômicos e moleculares em cultivares do morango (Fragaria $\mathrm{x}$ ananassa Duch.). $154 \mathrm{f}$. Tese (Doutorado em Genética e Melhoramento de Plantas) - USP, ESALQ, Piracicaba.

DEGANI C; ROWLAND LJ; LEVI A; HORTINSKI JA; GALLETTA GJ. 1998. DNA fingerprinting of strawberry (Fragaria $\mathrm{x}$ ananassa) cultivars using randomly amplified polymorphic DNA (RAPD) markers. Euphytica, 102: 247-253

FERREIRA ME; GRATTAPAGLIA D. 1996. Introdução ao uso de marcadores moleculares em análise genética. 2. ed. Brasília: EMBRAPACENARGEM, $220 \mathrm{p}$.

GRAHAM J; MCNICOL RJ; MCNICOL JW. 1996. A comparison of methods for estimation of genetic diversity in strawberry cultivars. Theoretical and Applied Genetic, 93: 402-406.

HANCOCK JF; CALLOW PA. 1994. Randomly amplified polymorphic DNAs in the cultivated strawberry, Fragaria $\mathrm{x}$ ananassa. Journal of the American Society for Horticulturae Science, 114 862-864.

LIMAMR;AUGUSTIN E; CHOER E, RASEIRA MCB. 2003. Caracterização de cultivares de pessegueiro e nectarineira por marcadores moleculares. Pesquisa Agropecuária Brasileira, 38: 349-355.
MULCAHY DL; CRESTI M; SANSAVINI S. 1993. The use of random amplified polymorphic DNA to fingerprint apple genotypes. Scientia Horticulturae, 54: 89-96.

MULTIPLANTA, Morango: cultivares, Disponível em: $<$ htttp:/www.multiplanta.com.br $>$ Acesso em: 13 de jan. de 2005 .

OLIVEIRA RP; CRISTOFANI M; MACHADO MA. 2001. Marcadores RAPD para mapeamento genético e seleção de híbridos de citros. Revista Brasileira de Fruticultura, 23: 477-481.

REICHERT LJ; MADAIL JCM. 2003. Aspectos socio-econômicos. In: SANTOS AM; MEDEIROS ARM. (Ed.) Morango; produção. Brasília: Embrapa Clima Temperado/Embrapa Informação Tecnológica, p. 12-15.

ROHLF FJ. 1993. NTSYS.PC; numerical taxonomy and multivariate analysis system. v. 1.8. New York: Exeter Publications.

RONQUE ERV. 1998. Cultura do morangueiro; revisão e prática. Curitiva: Emater-PR, 206 p. THONGTHIENG T; SMITAMANA P. 2003. Genetic relationship in strawberry cultivars and their progenies analyzed by isozyme and RAPD. ScienceAsia, 29: 1-5.

WILLIANS JG; KUBELINK AR; LIVAK KJ; RAFALSI LA; TINGEY SV. 1990. DNA polymorfism amplified by arbitrary primers are useful as genetic markers. Nucleic Acids, 18: 65316535 . 